\title{
Nucleolar Localization of myc Transcripts
}

\author{
VINCENT C. BOND†* AND BARBARA WOLD \\ Division of Biology, California Institute of Technology, Pasadena, California 91125
}

Received 16 December 1992/Returned for modification 10 January 1993/Accepted 19 February 1993

\begin{abstract}
In situ hybridization has revealed a striking subnuclear distribution of c-myc RNA transcripts. A major fraction of the sense-strand nuclear c-myc transcripts was localized to the nucleoli. myc intron 1-containing RNAs were noticeably absent from nucleoli, accumulating instead in the nucleoplasm. The localization of myc RNA to nucleoli was shown to be common to a number of diverse cell types, including primary Sertoli cells and several cell lines. Furthermore, nucleolar localization was not restricted to c-myc. N-myc and myoD transcripts also displayed this phenomenon. In contrast, $\gamma$-actin or lactate dehydrogenase transcripts did not display nucleolar localization. These observations suggest a new role for the nucleolus in transport and/or turnover of potential mRNAs.
\end{abstract}

Relatively little is known about the spatial distribution and compartmentalization of RNA within the nucleus or about the possible significance of subnuclear localization with respect to RNA processing, intranuclear turnover, or transport to the cytoplasm. One exception is the group of RNAs that are specifically localized in the nucleolus. These include rRNAs which are polymerase I transcripts and are the only RNAs known to be transcribed and processed in the nucleolus (reviewed in references 18, 45, and 56). Several other RNAs accumulate in the nucleolus following their synthesis at nonnucleolar sites (reviewed in reference 38). For example, 5S rRNA is transcribed by RNA polymerase III and transported to the nucleolus in association with the ribosomal protein L5 (58). Viroid RNAs also localize to and apparently replicate in the nucleolus $(20,52)$. Viroids are small plant viruses whose genomes contain a region homologous to part of the 5S rRNA both in primary sequence and in predicted secondary structure $(5,27,34)$. Thus, there is at least one mechanism available to mediate RNA accumulation in the nucleolus; it is used to provide 5S rRNA for ribosome assembly and apparently can be used by the viroids (58). Another distinct small RNA species, U3, is synthesized outside the nucleolus and assembled into a small nuclear ribonucleoprotein particle which subsequently accumulates in the nucleolus. Once in the nucleolus, it is thought to be involved in rRNA processing, ribosome assembly, or transport $(3,8,48,56,59,60,65)$.

Much less is known about the intranuclear spatial distribution of polymerase II gene products. In one recent study, the distribution within the nucleus of Epstein-Barr virus RNAs and of neu oncogene (erbB2) transcripts was examined by in situ hybridization with a fluorescent probe (37). In certain cases, striking localization to just one or a few sites was observed. On the basis of the specific pattern in individual cells, these localized signals were attributed to sites of transcription or pathways of export. In the series of experiments reported here, we have studied the subcellular spatial distribution of $m y c$ and $m y o D$ RNAs by in situ hybridization. A consistent localization of $m y c$ and $m y o D$ sense strand RNA to nucleoli was observed, whereas other polymerase II

\footnotetext{
* Corresponding author.

$\dagger$ Present address: Department of Biochemistry, Morehouse School of Medicine, 720 Westview Drive S.W., Atlanta, GA 303101495.
}

gene products such as $\gamma$-actin showed no detectable nucleolar accumulation.

\section{MATERIALS AND METHODS}

Animals. BALB/cJ mice were obtained from the Jackson Laboratory, and Swiss Webster mice were obtained from the Charles River Laboratory.

Cell lines. The human neuroblastoma cell line IMR-32 was obtained from the American Type Culture Collection (CCL127). This line was maintained in Eagle's minimal essential medium plus nonessential amino acids, Earle's balanced salts solution, and $10 \%$ heat inactivated fetal bovine serum. The other cell lines are derivatives of the NIH $3 \mathrm{~T} 3$ cell line and were maintained in Dulbecco's modified Eagle's medium plus $10 \%$ dialyzed fetal bovine serum. The cell line 10T1/2 aza-myoblast is a myogenic derivative of the fibroblast cell line C3H10T1/2 (11). This cell line was maintained in Dulbecco's modified Eagle's medium plus $10 \%$ dialyzed fetal bovine serum. $\mathrm{C} 2 \mathrm{C12}$, another myogenic cell line, was maintained in Dulbecco's modified Eagle's medium plus $20 \%$ dialyzed fetal bovine serum (4).

Plasmids. Plasmids were constructed by standard procedures (41). pMyc1-HA contains a 122-bp HindIII-AluI fragment from exon 1 inserted into a bluescript vector. Transcription by $\mathrm{T} 3$ polymerase of this plasmid cut with HindIII gives a 157-bp transcript that will hybridize to sense c-myc sequences. Transcription by $\mathrm{T} 7$ polymerase of the same plasmid cut with EcoRI produces a transcript that will hybridize to antisense c-myc sequences. pMyc23 contains a cDNA fragment containing exons 2 and 3 inserted into a bluescript vector. Transcription by SP6 of this plasmid cut with $X b a$ I yields a 1,500 -bp transcript that will hybridize to sense c-myc sequences. pNmycA contains a 153-bp PstIDraI fragment from the human N-myc gene inserted into a bluescript vector. The fragment covers the $3^{\prime}$ untranslated region of the $\mathrm{N}-m y c$ gene and is $100 \%$ homologous in this region with the mouse $\mathrm{N}-m y c$ gene. Transcription from BamHI-cut plasmid gives a 200-bp transcript that hybridizes to sense $\mathrm{N}-$ myc sequences. The I1A probe contains $1,545 \mathrm{bp}$, from the $X h o I$ site in exon 1 to the $X b a I$ site 33 bp before the beginning of exon 2, inserted into a bluescript vector. Because this vector is so big, it was cut with PvuII, which gave a fragment going from $191 \mathrm{bp}$ upstream of the $\mathrm{XbaI}$ site through the $X b a I$ site and the $\mathrm{T} 7$ transcription site to a second PvuII site farther downstream in the vector. There- 
fore, when transcribed, I1A gave a transcript containing only the $191 \mathrm{bp}$ upstream of the $X b a$ I site and hybridizing only to sense intron $1 \mathrm{c}$-myc sequences. The $\gamma$-actin plasmid was described previously $(14,15,17)$. The myoD plasmid was described by Miner and Wold (42).

Cell spreads. Tissue culture cell spreads were made by growing the cells directly on $22-\mathrm{cm}$ coverslips. The cells were plated on sterile, coated coverslips in $35-\mathrm{mm}$ plates containing the appropriate medium and grown until they were 25 to $50 \%$ confluent. The cell-coated coverslips were then removed and fixed in methanol-acetic acid $(4: 1)$ at $-20^{\circ} \mathrm{C}$ for $1 \mathrm{~h}$ or in $4 \%$ paraformaldehyde in phosphatebuffered saline at room temperature for $15 \mathrm{~min}$. They were then ethanol dehydrated, air dried, mounted on slides, and stored in drierite containers at $-20^{\circ} \mathrm{C}$.

In situ hybridization. Before being used for experiments, the slides were acetylated for $10 \mathrm{~min}$, dehydrated in successive ethanol washes, and dried. In certain cases, the slides were pretreated with $20 \mu \mathrm{g}$ of RNase A per $\mathrm{ml}$ in $0.5 \mathrm{M}$ $\mathrm{NaCl}-10 \mathrm{mM}$ Tris-Cl (pH 8.0)-1 mM EDTA or with $50 \mu \mathrm{g}$ of DNase I per $\mathrm{ml}$ in $50 \mathrm{mM}$ Tris-Cl (pH 7.5)-10 mM MgCl . The DNase-treated slides were subsequently washed thoroughly with $0.5 \mathrm{M} \mathrm{NaCl}-10 \mathrm{mM}$ Tris-Cl (pH 7.5)-0.1 M EDTA and then immediately acetylated (21).

${ }^{35} \mathrm{~S}$-labeled probe was made and purified essentially as described by Angerer et al. (2). The final concentrations of the components of the hybridization solution were $40 \mathrm{mM}$ Tris- $\mathrm{HCl}$ ( $\mathrm{pH} 7.5), 6 \mathrm{mM} \mathrm{MgCl}, 1 \mathrm{mM}$ dithiothreitol (DTT) for SP6 polymerase or $10 \mathrm{mM}$ DTT for T7 and T3 polymerases, $100 \mu \mathrm{M}$ each nucleoside triphosphate, $100 \mathrm{U}$ of RNase inhibitor per $\mathrm{ml}, 100 \mu \mathrm{g}$ of template DNA per $\mathrm{ml}$, and 1,200 to $1,800 \mathrm{U}$ of SP6, T7, or T3 polymerase per ml. The samples were incubated at $37^{\circ} \mathrm{C}$ for 1 to $2 \mathrm{~h}$. Incorporation was measured by acid-precipitable counts. The samples were $\mathrm{DNase}$ treated by being diluted to $50 \mathrm{mM}$ Tris- $\mathrm{HCl}(\mathrm{pH}$ 7.4)-10 mM $\mathrm{MgCl}_{2}$ and incubated at $37^{\circ} \mathrm{C}$ with $50 \mathrm{U}$ of RNase-free DNase I per $\mathrm{ml}$ for $30 \mathrm{~min}$. They were subsequently phenol extracted and ethanol precipitated. The probe was resuspended and stored in equal volumes of 20 mM DTT and deionized formamide. Hybridization was done by a variation of the procedure of Angerer et al. (2). The final concentrations of the components of the hybridization mix were $50 \%$ formamide, $20 \mathrm{mM}$ Tris- $\mathrm{HCl}(\mathrm{pH} 8.0), 1 \mathrm{mM}$ EDTA, $1 \times$ Denhardt's solution, $500 \mu \mathrm{g}$ of carrier tRNA per $\mathrm{ml}, 10 \%$ dextran sulfate, $100 \mu \mathrm{M}$ DTT, and various $\mathrm{NaCl}$ concentrations depending on the probe and hybridization temperature. The above mix was combined with enough probe to give 0.2 to $0.3 \mu \mathrm{g}$ of probe per $\mathrm{ml}$ per $\mathrm{kb}$ of probe complexity, which will just achieve saturation at the appropriate temperature in 12 to $15 \mathrm{~h}$. For the posthybridization washes, slides were put through three or four changes of $2 \times$ SSPE ( $1 \times$ SSPE is $0.18 \mathrm{M} \mathrm{NaCl}, 10 \mathrm{mM} \mathrm{NaPO}_{4}$, and $1 \mathrm{mM}$ EDTA [pH 7.7]) at room temperature for a total of $30 \mathrm{~min}$. The first pass, which was only 1 to $3 \mathrm{~min}$, removed the coverslip and most of the probe solution. The second and third passes were about 15 min each and involved a volume of 400 to $500 \mathrm{ml}$. Next, the slides were washed in two changes of high-stringency buffer $(2 \mathrm{mM} \mathrm{NaPP}, 1 \mathrm{mM}$ $\mathrm{NaPO}_{4}$ [pH 7.2], and $1 \mathrm{mM}$ disodium EDTA) at $55^{\circ} \mathrm{C}$ for 30 min each. Finally, they were washed in $0.1 \times$ SSPE at room temperature, dehydrated sequentially in $30,50,70$, and $95 \%$ ethanol containing $300 \mathrm{mM}$ ammonium acetate, and air dried. Autoradiography and development were done exactly as described by Angerer et al. (2).

Cytological staining. The slides were stained by several different methods. Chromatin staining was done with
Hoechst dye 33342 at $1 \mu \mathrm{g} / \mathrm{ml}$ for 1 to $2 \mathrm{~h}$ (long staining times were required to penetrate the emulsion and reach the cells). Methyl green-pyronine $Y$ was used to visualize nucleoli, which stained red, and DNA, which stained bluish green (28). An adaptation of a one-step procedure of silver staining was also used for visualization of the nucleoli $(25,26)$. In this adaptation, slides were differentially stained after development of photographic emulsion, producing nucleoli which are golden brown rather than black. This allowed simultaneous visualization of the autoradiograph grains and the nucleolus.

\section{RESULTS}

Initial observation and controls. We examined the subcellular distribution of c-myc transcripts in several cell types by in situ hybridization. Hybridization of ${ }^{35} \mathrm{~S}$-labeled c-myc RNA probes was detected by autoradiography, and the cells were visualized by histochemical staining. The grains over a cell were subsequently counted and subdivided into cellular compartments (cytoplasm, nucleus, nucleolus, and nucleoplasm), and the results are presented in tabular form. In selected cases, photomicrographs substantiating our data are presented. An entirely unexpected subnuclear localization was observed in NIH 3T3 cells probed for sense strand c-myc RNA (Fig. 1a; Table 1). Within the nuclei, grains were clearly localized in one or a few regions. In the cytoplasm, grains were distributed in a diffuse pattern. Control experiments confirmed that the observed nuclear signal was due to hybridization with RNA and not with DNA. One such experiment compared the patterns observed by using probes for sense myc RNA (Fig. 2c) with those found using probes for antisense myc RNA (Fig. 2a). If hybridization with DNA was responsible for the observed signal, the same pattern would be expected for both sense and antisense probes. The antisense probe gave much less overall labeling, and little to no subnuclear localization was detected. However, because the c-myc gene does make antisense RNA (44), some hybridization signal would be expected, and this was indeed observed (Fig. 2a). To confirm that the observed hybridization was not due to DNA, cytological preparations were pretreated with DNase and the enzyme was inactivated and then hybridized. The observed signal was unaffected by DNase predigestion (Table 2). Artifacts can also arise, in some cases, as a result of the method of fixation. The pattern observed was not dependent on a single fixation method, since NIH 3T3 cell monolayers fixed with either methanolacetic acid or paraformaldehyde displayed the same c-myc signal distribution (data not shown). Finally, similar preparations of cells were probed with an intron 1 c-myc probe (Table 2), giving an entirely different grain distribution. More overall labeling was observed, and the vast majority of the nuclear grains were distributed over the nucleoplasm rather than being localized over nucleoli, suggesting that this signal could not be due to DNA hybridization. We conclude that the labeled probes are hybridizing to c-myc RNA and that the unusual subnuclear signal localization is specific for sense, exonic sequences.

The restricted nuclear distribution of c-myc RNA was assigned to nucleoli by three independent criteria. First, preparations of NIH 3T3 cells were made and histologically stained with either silver stain (46) or methyl green-pyronine Y (28) (Fig. 1b and c). Silver has been a classical stain used to visualize nucleoli; it stains them golden brown to black as a result of preferential reaction with nucleolar organizing region proteins, in particular nucleolin $(26,56,57)$. Methyl 

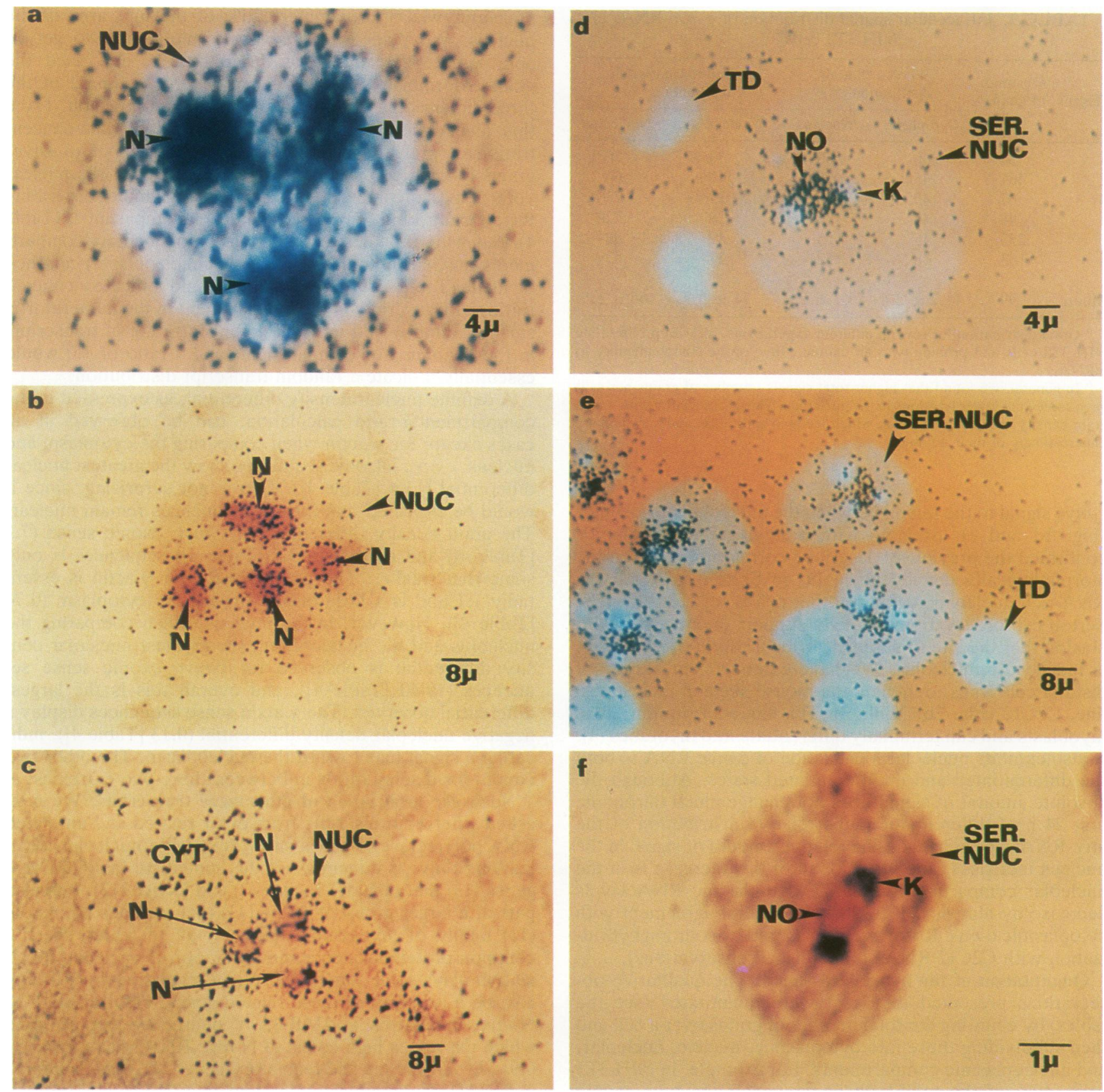

FIG. 1. Intranuclear distribution of c-myc RNA expression in both primary and established cells. (a to c) Photomicrographs of NIH 3T3 cell in situ hybridizations with a c-myc exonic riboprobe. (d to f) Photomicrographs of in situ hybridizations of primary mouse testis cells, also with a c-myc exonic riboprobe. Panel a shows a cell stained with Hoechst stain to visualize the nucleus and gives an overexposed view of the subnuclear signal localization. In both panels b (a cell stained for RNA with methyl green-pyronine $\mathrm{Y}$ ) and $\mathrm{c}$ (a cell stained with silver), the grains can be seen accumulating over the nucleolar region of the cell nucleus. Panel $d$ is a Hoechst-stained Sertoli cell displaying the prominent nuclear karyosome characteristic of adult-mouse Sertoli cells. Spermatids are also visible. A view showing several Hoechst-stained Sertoli cells can be seen in panel e, displaying the consistent pattern of grain localization between the two karyosomes, which in panel $\mathrm{f}$ is now stained for RNA with methyl green-pyronine Y, making the nucleolar organizing region visible. Abbreviations: NUC, nucleus; N, nucleolus; CYT, cytoplasm; TD, spermatids; NO, nucleolar organizer; K, karyosome; SER. NUC, Sertoli nucleus.

green-pyronine $\mathrm{Y}$ is an alternative histological reagent that stains DNA greenish blue to brown and RNA (which is in high local concentration in the nucleoli of proliferating cells) red. With either staining method, the c-myc sense strand exon RNA appeared to consistently localize over what is histologically identified as the nucleolus.

Further evidence of nucleolar localization came from concurrent studies of myc RNA in mouse testis cells. The Sertoli cell population in adult mouse testis has a prominent, highly distinctive nucleolar morphology. It consists of easily visualized, paired nucleolar karyosomes with the nucleolar organizing region spanning the region between these structures (Fig. 1e) (12). In situ hybridization of spreads of adult mouse testis cells revealed prominent localization of the 
TABLE 1. Intracellular spatial distribution of c-myc RNAs in NIH 3T3 cells

\begin{tabular}{|c|c|c|c|c|c|}
\hline \multirow[t]{2}{*}{ Expt } & \multirow{2}{*}{$\begin{array}{l}\text { Mean no. } \\
\text { of grains/ } \\
\text { cell }\end{array}$} & \multicolumn{2}{|c|}{$\begin{array}{l}\text { Whole-cell grain } \\
\text { distribution }(\%)^{a}\end{array}$} & \multicolumn{2}{|c|}{$\begin{array}{l}\text { Intranuclear grain } \\
\text { distribution }(\%)^{a}\end{array}$} \\
\hline & & Cytoplasm & Nucleus & Nucleoplasm & Nucleolus $^{b}$ \\
\hline 1 & 38 & 40 & 60 & 30 & 70 \\
\hline 2 & 461 & 45 & 55 & 40 & 60 \\
\hline 3 & 67 & 45 & 55 & 27 & 73 \\
\hline 4 & 48 & 45 & 55 & 28 & 72 \\
\hline 5 & 233 & 45 & 55 & 42 & 58 \\
\hline 6 & 183 & 48 & 52 & 37 & 63 \\
\hline
\end{tabular}

Mean $\quad 99 \quad 44.7 \pm 2.4 \quad 55.3 \pm 2.4 \quad 34 \pm 5.9 \quad 66 \pm 5.9$

${ }^{a}$ Grain distribution for several different experiments, all with proliferating NIH 3T3 cells and probing with an exonic c-myc probe complementary to mRNA.

$b$ In general, we found that higher total signals (number of grains per cell) gave somewhat lower fractions in the nucleolus. This is associated with a high grain density over the nucleolus, which leads to saturation and a systematic underestimate of their number.

c-myc signal to the region between the nucleolar karyosomes (Fig. 1d and e). Staining with methyl green-pyronine $Y$ confirmed the previously described correlation between the morphologically defined nucleolus in Sertoli cells and the RNA-rich nucleolar region of other cell types (Fig. 1f). The Sertoli cell observations strongly support the previous conclusion that the site of subnuclear localization of myc RNA is indeed the nucleolus. We have extended our survey of distinct cell types to include the mouse skeletal muscle cell line, $\mathrm{C} 2 \mathrm{C} 12$ (Fig. 2b; Table 3). This line can proliferate as myoblasts and can terminally differentiate into myotubes (4). It also exhibits nucleolar localization of c-myc RNA in both the differentiated and undifferentiated states. Although the absolute amount of signal does not change much during the first $24 \mathrm{~h}$ of differentiation, the relative distribution of the $m y c$ RNAs does change. The relative amount of signal in the nucleus increases, and virtually all of this increase is in the nucleolar compartment. Relative cytoplasmic RNA levels decrease by almost half to $28 \%$, in general agreement with cytoplasmic c-myc RNA levels measured by solution hybridization with $\mathrm{C} 2 \mathrm{C} 12$ RNAs (unpublished observations).

Quantitation of the hybridized signal. The qualitative observations presented in Fig. 1 were quantitated (see the tables) by counting the total number of grains over a cell and then subdividing these into cytoplasmic, nucleic, nucleolar, and nucleoplasmic compartments. For example, in NIH 3T3 cells, $40 \%$ of the total cellular grains for the myc exonic probe are in the cytoplasm and $60 \%$ are in the nucleus (Table 1). Furthermore, of the $60 \%$ that are nuclear, $70 \%$ are in the nucleolus and $30 \%$ are in the nucleoplasm. We have assigned to the nucleolar category only the grains directly over the histologically defined organelle. It is possible that a significantly larger fraction of the nuclear myc transcripts are, in fact, nucleolar, since some grains appearing over nucleoplasm in these experiments may actually be misassigned owing to the path length of the ${ }^{35} \mathrm{~S}$ beta-particle. Moreover, because the cultured cells are actively moving through the cell cycle, a fraction of them (for example, those in late $G_{2}$ and mitosis) do not have a distinct nucleolar organelle. Therefore, only cells with distinct nucleoli were considered for examination. To attempt to evaluate the relative concentration in the various compartments, we measured the area occupied by each compartment by using the photographic image. In NIH 3T3 cells, for example, this area for the nucleolus was approximately $20 \%$ of the unit area of the nucleus. We then used the area formula, $\pi r^{2}$, to get an approximate calculation of the radius, $r$, and used the volume formula, $4 \pi r^{3} / 3$, to get a relative estimate of the three-dimensional volume of the nuclei and nucleoli. From this, an estimate could be made of the relative grain concentration or grain density by dividing the number of silver grains in each compartment by the estimate of the nuclear volume in that compartment, arriving at a number describing the concentration of transcripts in each compartment (Table 4). A density ratio between the two complementary compartments (nucleus/cytoplasm; nucleolus/nucleoplasm) can then be made (Table 4). A large number would indicate a concentrating of transcripts in the compartment in the numerator, a small fraction would indicate a concentrating of transcripts in the denominator compartment, and a ratio of 1.0 would essentially indicate a random transcript distribution.

A definite nuclear density differential, as expressed in the compartmental-ratio calculation, can be observed in all cases except for $\gamma$-actin when comparing the cytoplasm and nucleus. c-myc intronic sequences show the greatest nuclear differential (13.4 [Table 4]). This is not surprising, since it would be expected that intronic sequences remain nuclear. The grain density differential for c-myc exonic sense (7.5 [Table 4]) and antisense (6.5 [Table 4]) sequences is only somewhat smaller. The grain density for $\gamma$-actin is essentially $1: 1$ and is a little biased toward the cytoplasm $(0.74$ [Table 4]). However, in the nucleus, when comparing the nucleolus and the nucleoplasm, the greatest nucleolar density differential is observed for c-myc exonic sense sequences (19.40 [Table 4]), and overall this is the largest differential observed. The $\boldsymbol{\gamma}$-actin sense sequences display a negative nucleolar density differential (0.13 [Table 4]), indicating a signal bias toward the nucleoplasm. The other two conditions display ratios in between these two extremes.

Nucleolar localization of other gene transcripts. We next asked whether transcripts from other related and unrelated RNA polymerase II genes show detectable nucleolar localization. c-myc is a member of the immediate family of myc genes (13) that includes N-myc (7) and L-myc (13). It is also part of a larger group of genes (43) that includes the myoD (11) family of myogenic regulators, all of which share a common protein sequence motif $(42,50)$. If nucleolar localization plays some functional role in regulating $m y c$, it may also be a property of these related genes. Hybridization to $\mathrm{N}-m y c$ transcripts in IMR-32, a neuroblastoma cell line which expresses high levels of $\mathrm{N}-m y c$ RNA, was examined (49). myoD, the muscle regulatory gene (11), was examined in 10T1/2 aza-myoblasts (11) and in C2C12s (4), both of which are myogenic cell lines that express myoD. Finally, we examined $\gamma$-actin transcripts in NIH 3T3 cells as a gene entirely unrelated to the myc-like regulators. The results of these experiments are given in Table 3. Prominent accumulation of signal over the nucleolus of IMR-32 cells was observed when using the N-myc probe for sense RNA (Fig. 3a). Most $(70 \%)$ of the total cell signal was nuclear, and approximately $60 \%$ of the nuclear signal was over nucleoli. In both myogenic cell lines (10T1/2 and $\mathrm{C} 2 \mathrm{C} 12)$, myoD1 showed significant nucleolar signal localization (Fig. 3b). Under growth conditions in 10T1/2 and C2C12 cells, 46 and $59 \%$, respectively, of the total cellular signal was nuclear, with 63 and $74 \%$, respectively, of that nuclear signal over nucleoli. Alternatively, actin displays no detectable nucleolar accumulation. The $\gamma$-actin signal was primarily cytoplasmic (89\%), as reported previously (36), and grains over the nucleus were not detectably localized. Further, in a separate 


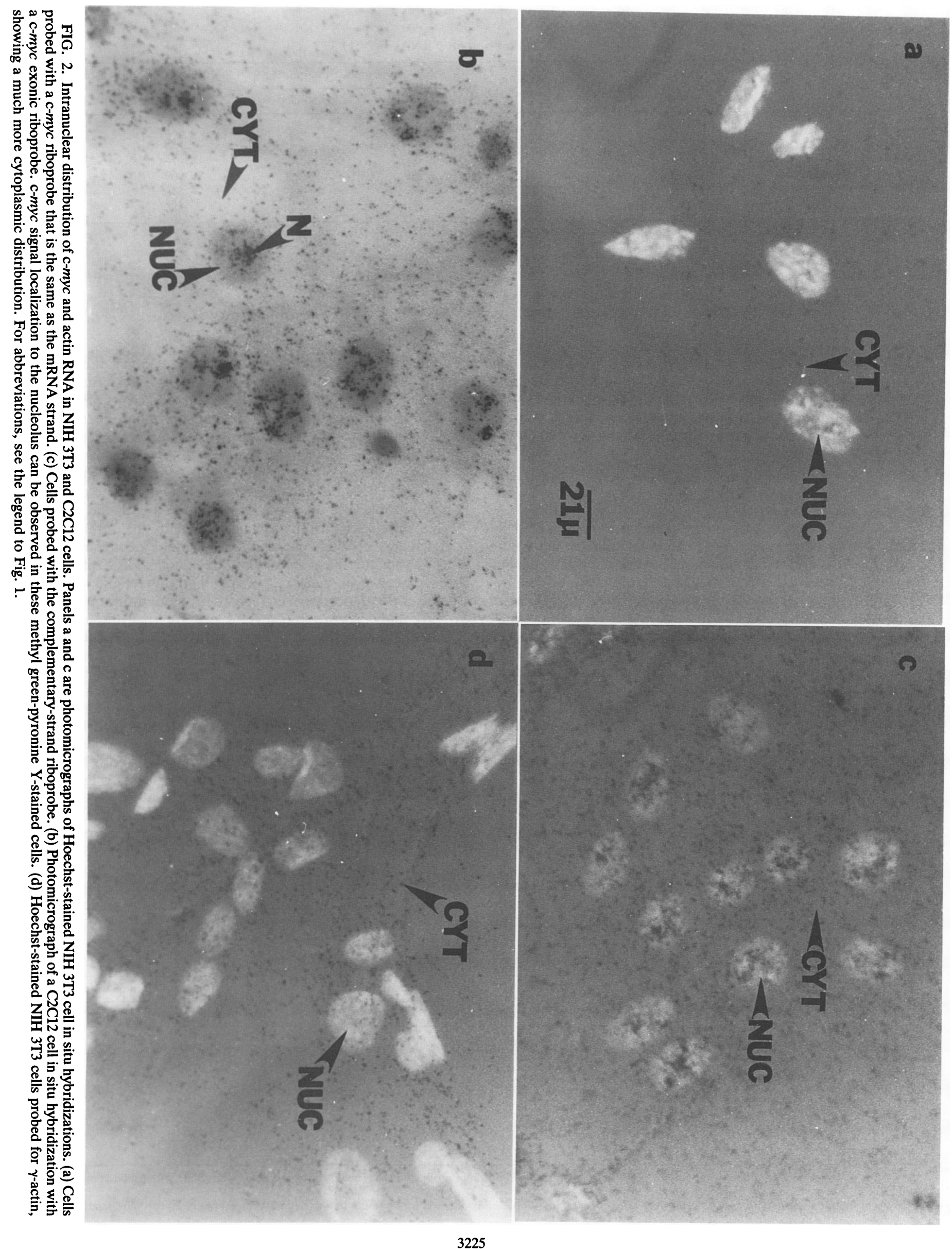


TABLE 2. Distribution of c-myc RNAs in NIH 3 T3 cells

\begin{tabular}{|c|c|c|c|c|c|c|}
\hline \multirow{2}{*}{ RNA detected ${ }^{a}$} & \multirow{2}{*}{ Treatment $^{b}$} & \multirow{2}{*}{$\begin{array}{l}\text { Mean no. of } \\
\text { grains/cell }\end{array}$} & \multicolumn{2}{|c|}{ Whole-cell grain distribution $(\%)$} & \multicolumn{2}{|c|}{ Intranuclear grain distribution (\%) } \\
\hline & & & Cytoplasm & Nucleus & Nucleoplasm & Nucleolus $^{a}$ \\
\hline Exonic $^{c}$ sense $^{d}$ & Untreated & 99 & 45 & 55 & 36 & 64 \\
\hline Exonic, ${ }^{c}$ sense & DNAse pretreated & 98 & 46 & 54 & 39 & 61 \\
\hline Intronic ${ }^{c}$ sense & Untreated & 257 & 31 & 69 & 74 & 26 \\
\hline Exonic, $^{c}$ antisense $e^{e}$ & Untreated & 64 & 48 & 52 & 69 & 31 \\
\hline Exonic, ${ }^{f}$ sense & Untreated & 124 & 46 & 54 & 40 & 60 \\
\hline Actin, sense & Untreated & 268 & 89 & 11 & $>99$ & $<1$ \\
\hline
\end{tabular}

${ }^{a}$ Indicates the target sequence detected by the probe used in that set of experiments.

$b$ Cells were treated as indicated, and the enzyme was inactivated before hybridization.

${ }^{c}$ Probe used is pMycl-HA.

d Strand complementary to mRNA.

e Strand same as mRNA.

$f$ Probe used is pMyc23.

but similar set of in situ experiments (63), a diffuse, wholecell signal distribution was observed when lactate dehydrogenase B RNA probes were used in mouse Sertoli cells. Thus, within the limited group of genes examined, only the myc/myoD genes displayed detectable transcript accumulation in the nucleolus.

\section{DISCUSSION}

The nucleolus is a complex, subnuclear organelle that differs from other organelles in lacking a membrane boundary (18). It is architecturally quite complex and is a dynamic structure, coalescing into a discrete organelle as the cell moves through $G_{1}$ into the $S$ phase and subsequently disintegrating as the cell moves through $\mathrm{G}_{2}$, becoming cytologically invisible in late $G_{2}$ and mitosis (1). The only function presently assigned to the nucleolus is rRNA synthesis and assembly of ribosomes $(6,18,19)$. Although no other functions have been associated with the nucleolus, the possibility of additional cellular duties remains. Our observation that transcripts from some polymerase II genes accumulate to detectable levels in the nucleolus suggests that this organelle may serve a posttranscriptional function affecting potential mRNAs.

We have observed substantial nucleolar localization of c-myc, N-myc, and myoD1 RNA transcripts, whereas $\gamma$-actin showed no concurrent localization. Further, independent in situ experiments have shown that lactate dehydrogenase B has a diffuse distribution in mouse Sertoli cells (63), whereas we observed c-myc primarily localized to the nucleolus. Although it is difficult to generalize broadly from the limited set of gene transcripts examined thus far, there is one common characteristic of the localizing RNAs that distinguishes them from the nonlocalizing transcripts. Both myc and $m y o D$ transcripts have relatively short half-lives $(10,31$, $39,62)$. It is possible that their rapid turnover in the cytoplasmic compartment leads to relatively high total nuclear levels, which are easily visualized in the in situ assay. By contrast, actin transcripts are relatively stable and have high cytoplasmic accumulation compared with the nucleus. This high cytoplasmic signal relative to the total nuclear signal may preclude detection of nucleolar localization, even if it exists for these transcripts. Nucleolar localization may therefore be a general phenomenon detectable only for transcripts that turn over rapidly in the cytoplasm.

We have shown by several criteria that the nucleolar signal is due to the reaction of probe with RNA rather than DNA and that exonic sequences are detected in the nucleolus whereas intronic sequences are almost exclusively nucleoplasmic. One possibility we have considered is that the observed nucleolar localization is the RNA probe hybridizing to nucleolar rRNA. This has been observed by other investigators. However, we have used these probes repeatedly in Northern (RNA) hybridizations with both NIH 3T3 RNA and Sertoli cell RNA under much less stringent conditions of hybridization and posthybridization washes, and we have never observed any hybridization to the rRNA bands. Another possibility that has been considered is that the observed strand and sequence preferences reflect the presence of a nucleolar protein that selectively binds some RNA probe sequences while not binding others. Again, the stringent posthybridization wash conditions argue against

TABLE 3. Intracellular spatial distribution of other RNAs and cells

\begin{tabular}{|c|c|c|c|c|c|c|}
\hline \multirow{2}{*}{ Cell type } & \multirow{2}{*}{ Probe } & \multirow{2}{*}{$\begin{array}{l}\text { Mean no. of } \\
\text { grains/cell }\end{array}$} & \multicolumn{2}{|c|}{ Whole-cell grain distribution $(\%)^{a}$} & \multicolumn{2}{|c|}{ Intranuclear grain distribution $(\%)^{a}$} \\
\hline & & & Cytoplasm & Nucleus & Nucleoplasm & Nucleolus $^{b}$ \\
\hline NIH 3 T3 & $c-m y c$ & 99 & 45 & 55 & 37 & 63 \\
\hline NIH 3 T3 & $\gamma$-Actin & 268 & 89 & 11 & $>99$ & $<1$ \\
\hline IMR-32 & $\mathrm{N}-m y c$ & 299 & 30 & 70 & 43 & 57 \\
\hline Sertoli & c-myc & 277 & 18 & 82 & 43 & 57 \\
\hline 10T.5, AzaM & myoD & 24 & 54 & 46 & 37 & 63 \\
\hline $\mathrm{C} 2 \mathrm{C} 12$ & myoD & 13 & 41 & 59 & 26 & 74 \\
\hline $\mathrm{C} 2 \mathrm{C} 12$ & c-myc & 19 & 42 & 58 & 26 & 74 \\
\hline $\mathrm{C} 2 \mathrm{C} 12$ & c-myc & 16 & 28 & 72 & 20 & 80 \\
\hline
\end{tabular}

${ }^{a}$ Grain distribution with different probes on NIH 3T3 cells and several different probes on other cells. All experiments were done with probe complementary to mRNA.

${ }^{b}$ In this set of experiments, $\mathrm{C} 2 \mathrm{C} 12$ cells were grown under differentiation conditions for 24 hours before being fixed and prepared for hybridization. 
TABLE 4. Density comparisons between intracellular compartments

\begin{tabular}{|c|c|c|c|c|c|}
\hline \multirow{2}{*}{ RNA detected } & \multirow{2}{*}{$\begin{array}{l}\text { Mean no. of } \\
\text { grains/cell }\end{array}$} & \multicolumn{4}{|c|}{ Compartment grain density ${ }^{a}$ (grains/unit vol) } \\
\hline & & Cytoplasm & Nucleus (ratio) ${ }^{b}$ & Nucleoplasm & Nucleolus (ratio) ${ }^{b}$ \\
\hline c-myc, sense, exon & 99 & 52 & $385(7.45)$ & 39 & $754(19.40)$ \\
\hline$c-m y c$, antisense, exon & 64 & 36 & 234 (6.53) & 25 & $134(5.38)$ \\
\hline c-myc, sense, intron & 257 & 93 & $1,245(13.41)$ & 142 & $599(4.20)$ \\
\hline$\gamma$-Actin, sense & 268 & 278 & $207(0.74)$ & 32 & $4(0.13)$ \\
\hline
\end{tabular}

${ }^{a}$ The compartment grain density is an estimate of the relative grain concentration in each compartment and thus of the relative concentration of transcripts in each. By using the photographic image, the area occupied by each compartment was measured for NIH 3T3 cells. The nucleus occupies $33 \%$ of the unit area of the cell, and the cytoplasm occupies $67 \%$. The nucleolus occupies $22 \%$ of the unit area of the nucleus, with the nucleoplasm occupying $78 \%$. By using the area formula for a circle $\left(\pi r^{2}\right)$, the radius is calculated and then used to calculate the relative volume for each compartment. Then, compartment grain density is calculated by dividing the number of grains per compartment by the relative volume per compartment.

$b$ The ratio between the two complementary compartments: nucleus/cytoplasm, and nucleolus/nucleoplasm.

this possibility. Having shown that RNA transcripts are detected in the nucleolus, the question of differential retention of transcripts in the different compartments arises. It is possible that nucleolar transcripts are preferentially retained during fixation and hybridization, giving a false impression of the actual percentage of transcripts in that compartment when compared with the other compartments. However, our central conclusions do not rely heavily on the absolute numbers but, instead, focus mainly on relative values when probes for different gene products or different portions of $m y c$ are used. Thus, similarities are clearly observed in the transcript distribution for $m y c$ and $m y o D$, and differences are clearly seen when that distribution is compared with that of actin. Several initial conclusions about the nucleolar localization of transcripts can be drawn from our data with probes specific for different portions of the genes studied. First, c-myc transcripts localized to the nucleolus contain exon 1 sequences but lack intron 1 sequences and must therefore be at least partially processed. Second, both $\mathrm{N}-m y c$ - and myoD1-localized transcripts contain the $3^{\prime}$ untranslated regions, suggesting that these are not prematurely truncated transcripts. Third, the genes whose RNAs show significant nucleolar localization have different chromosomal locations $(22,23,29,53,61)$. This third conclusion appears to rule out simple positioning of these genes near the ribosomal genes as the source of nucleolar localization. Additional mapping of localized transcripts will be required to determine whether processing of the $3^{\prime}$ end has occurred.

Our observations are consistent with the possibility that transient association with the nucleolus is an integral part of the maturation or transport pathway of $m y c$ and $m y o D$ mRNAs. Evidence from other studies also supports the possibility that the nucleolus plays a significant role in the biogenesis of diverse, nonribosomal RNAs. For example, viroid RNAs, which are polymerase II transcripts, are localized in the nucleolus (20). However, the 5S-like features of viroid RNAs thought to mediate this localization $(5,27$, 34) were not detected in our search of myc and myoD sequences. A second example that the nucleoli have the potential for other functions comes from observations made in yeast cells (47). Using immunofluorescence microscopy and immunoelectron microscopy, these investigators observed that the abundant yeast small nuclear RNAs were localized in the electron-dense region of the nucleus, which has classically been called the nucleolar portion of the nucleus. Because other functional domains may be localized here, these authors have suggested that this region should be referred to as the non-chromatin-enriched area of the nucleus rather than the nucleolus. We would argue that, on the basis of our results, there is no qualitative difference in this region between mammalian and yeast cells. The difference is mainly quantitative, i.e., in the amount of polymerase II activity that takes place in the nucleolus.

A third example of a connection between polymerase II transcript biogenesis, posttranscriptional processing, and the nucleolus comes from a study of the effect of dihydrofolate reductase (dhfr) nonsense mutations on the processing of same transcripts (64). The authors were able to show that translation termination mutations in any of the internal exons of the $d h f r$ gene gave rise to a low-RNA phenotype. Further experiments suggested that this effect was not due to transcription rates or to RNA stability and that this phenotype could be reversed through the reversion of the original mutation. In their model, they proposed a modification of the translation translocation model (67) in which the process of protein synthesis itself pulls the translatable RNA molecules through the pores and out of the nucleus. This model thus assumes that the mRNAs interact with ribosomes or preribosomes and that they are close to the nuclear pores, all of which suggest that these events occur in the nucleolus.

A final connection of nucleoli with nonribosomal RNAs is emerging from studies of human T-cell leukemia virus type I (HTLV-I), and human immunodeficiency virus. HTLV-I and human immunodeficiency virus both code for proteins, Rex $(24,30)$ and $\operatorname{Rev}(55)$, respectively, which are powerful posttranscriptional regulators of the levels of a subset of viral transcripts $(16,40,51)$, although their mechanism of action is currently not known. Interestingly, Rev and Rex are localized in nucleoli $(9,54)$, raising the possibility that the nucleolus or a nucleolar component is crucial to Rex and Rev regulation.

Kanamori et al. (33) and White et al. (66) showed that correct expression of the Rex protein in human $T$ cells or in transfected COS cells reduces the rate of interleukin-2R $\alpha$ (IL-2R $\alpha$ ) mRNA degradation. This was shown not to be due to an effect on transport from nucleus to cytoplasm but appeared to be due to stabilization of the cellular mRNA. Further, when mutations were introduced into the nucleolustargeting signal of Rex, so that the protein was made but localized to the nucleoplasm instead of the nucleolus, this stabilization of the IL-2R $\alpha$ transcripts did not occur. Finally, when a substitution mutation which rescued the original mutation was introduced, Rex again localized to the nucleolus and IL-2R $\alpha$ mRNA was again stabilized. From these data, an effect being exerted on a cellular mRNA from the nucleolus can be observed.

Kalland et al. (32) showed that the presence of the Rex protein in COS cells significantly increased the accumulation of the HTLV-I env transcripts in the nucleolus. This raises the possibility that Rex directs unspliced viral mRNA to the 

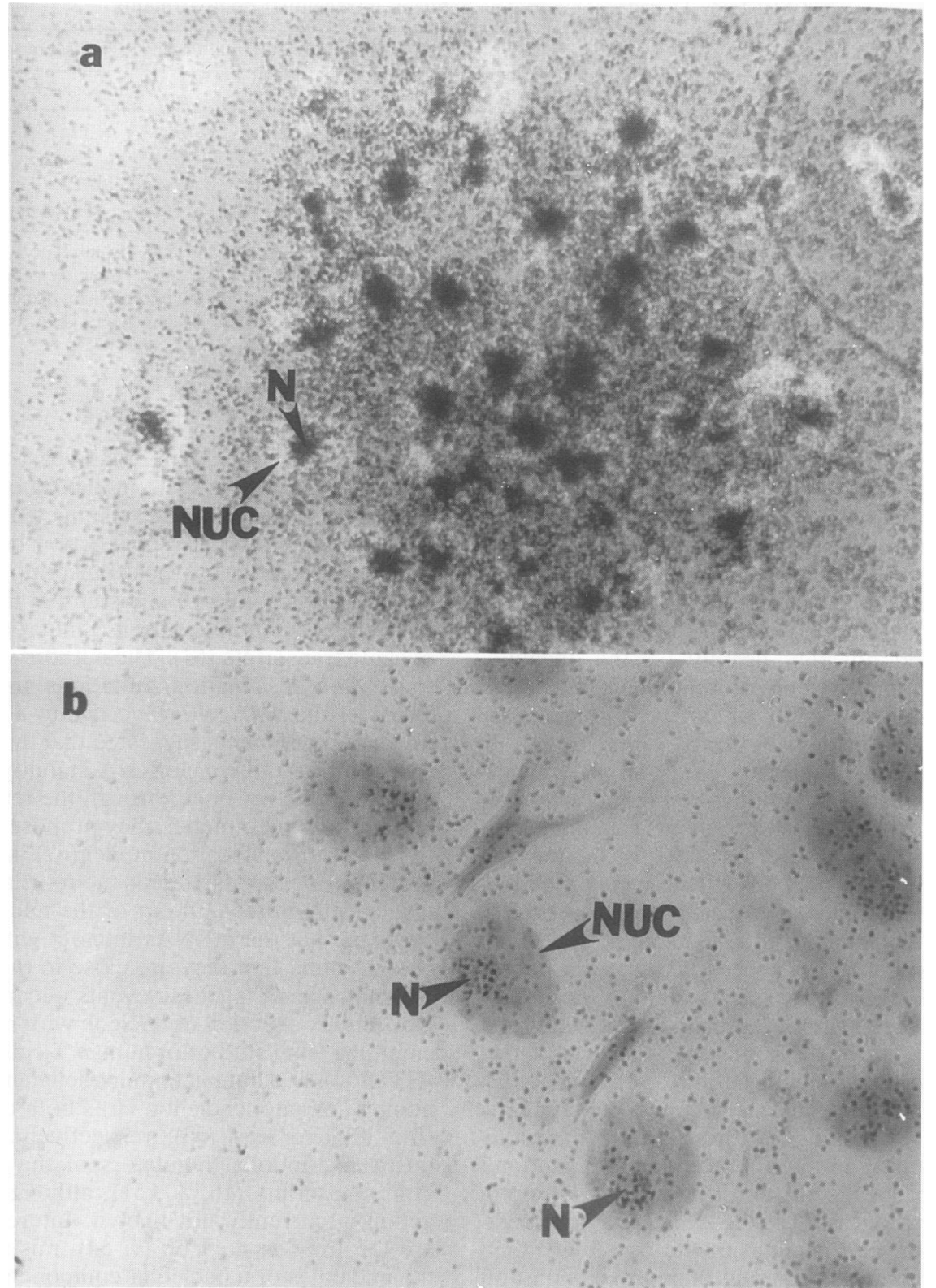

FIG. 3. Intranuclear distribution of N-myc and myoD RNA in IMR-32 and C2C12 cells. (a) Photomicrograph of Hoechst-stained IMR-32 cell in situ hybridization probed with an $\mathrm{N}$-myc riboprobe that is the complement of the mRNA strand. This is purposely overexposed to show the highly localized grain distribution to a subnuclear compartment, which is the nucleolus. (b) Photomicrograph of a C2C12 cell in situ hybridization with a myoD exonic riboprobe. Signal localization to the nucleolus can be observed in these silver-stained cells. For abbreviations, see the legend to Fig. 1.

nucleolus to be exported to the cytoplasm for translation. They suggest that this may provide a means for RNAs containing splice recognition signals to exit the nucleus in the unspliced form.

The functional significance of nucleolar localization of any of these nonribosomal RNAs is presently unknown, but there are several intriguing possibilities. One is that some species of polymerase II transcripts routinely pass through the nucleolus on their way to the cytoplasm, where they function as mRNAs. Since the mechanism of mRNA export from the nucleus to the cytoplasm is very poorly understood, a role for the nucleolus seems quite plausible. Our data are consistent with this possibility but do not rule out others.
For example, the transcripts that accumulate in the nucleolus may be destined not for export but, rather, for turnover. In this case the nucleolus may be an important site of intranuclear turnover in which imperfectly processed RNAs accumulate and are destroyed. Alternatively, the nucleolus may be the site of quantitative regulation of properly processed prospective mRNAs, such that excess transcripts are fed into a nucleolar turnover pathway. For RNAs such as myc that encode proteins playing a prominent role in regulating cell growth and proliferation (35), it is tempting to speculate that nucleolar association may be part of a pathway linking translational capacity with other aspects of cell growth and division. Finally, although variation among 
transcripts from different genes would appear to argue otherwise, it is possible that the nucleolar transcripts are simply gratuitously associated with nucleolar components. In this case, the observed localization would reveal a previously unappreciated degree of exchange between nucleoplasm and nucleolus. Further studies will focus on identification of the structural features that mediate nucleolar accumulation. Together with assays of their functional significance for mRNA production, these studies should aid in discriminating among the possible functions.

\section{ACKNOWLEDGMENTS}

We thank Jesus del Mazo and Ellen Rothenberg for their assistance with in situ hybridization techniques. We also thank Jeff Miner, Paul Garrity, and Sean Tavtigian of the Wold group for hybridization probes. Finally, we thank John Abelson, Richard Axel, and members of the Wold group for their comments on the manuscript.

This work was supported by grants from the Lucille Markey Charitable Trust and the National Institutes of Health.

\section{REFERENCES}

1. Anastassova-Kristeva, M. 1977. The nucleolar cycle in man. J. Cell Sci. 25:103-110.

2. Angerer, L. M., M. H. Stoler, and R. C. Angerer. 1987. In situ hybridization with RNA probes: an annotated recipe, p. 42-70. In $\mathrm{K}$. Valentino, J. Eberwine, and J. Barchas (ed.), In situ hybridization applications to neurobiology. Oxford University Press, Oxford.

3. Bachellerie, J. B., B. Michot, and F. Raynal. 1983. Recognition signals for mouse pre-rRNA processing. Mol. Biol. Rep. 9:7986.

4. Blau, H. M., G. K. Pavlath, E. C. Hardeman, C. P. Chin, L. Silberstein, S. G. Webster, S. C. Miller, and C. Webster. 1985. Plasticity of the differentiated state. Science 230:758-766.

5. Branch, A. D., B. J. Benenfeld, and H. D. Robertson. 1985. Ultraviolet light-induced crosslinking reveals a unique region of local tertiary structure in potato spindle tuber viroid and Hela RNA. Proc. Natl. Acad. Sci. USA 82:6590-6594.

6. Busch, H., and K. Smetana. 1970. The nucleolus. Academic Press, Inc., New York.

7. Cole, M. D. 1986. The myc oncogene: its role in transformation and differentiation. Annu. Rev. Genet. 20:361-384.

8. Crouch, R. J., S. Kanaya, and P. L. Earl. 1983. A model for the involvement of the small nucleolar RNA(U3) in processing eukaryotic ribosomal RNA. Mol. Biol. Rep. 9:75-78.

9. Cullen, B. R., J. Hauber, K. Campbell, J. G. Sodroski, W. A. Haseltine, and C. A. Rosen. 1988. Subcellular localization of the human immunodeficiency virus trans-acting art gene product. J. Virol. 62:2498-2501.

10. Dani, C. H., J. M. Blanchard, M. Piechaczyk, S. El Sabouty, L. Marty, and P. H. Jeanteur. 1984. Extreme instability of myc mRNA in normal and transformed human cells. Proc. Natl. Acad. Sci. USA 81:7046-7050.

11. Davis, R. L., H. Weintraub, and A. B. Lassar. 1987. Expression of a single transfected cDNA converts fibroblasts to myoblasts. Cell 51:987-1000.

12. del Mazo, J., M. J. Martin-Sempere, L. Kramer, and J. Avila. 1986. Centromere pattern in different mouse seminiferous tubule cells. Cytogenet. Cell Genet. 43:201-206.

13. DePinho, R., L. Mitsock, K. Hatton, P. Ferrier, K. Zimmerman, E. Legouy, A. Tesfaye, R. Collum, G. Yancopoulos, P. Nisen, R. Kriz, and F. Alt. 1987. Myc family of cellular oncogenes. J. Cell. Biochem. 33:257-266.

14. Enoch, T., K. Zinn, and T. Maniatis. 1986. Activation of the human beta-interferon gene requires an interferon-inducible factor. Mol. Cell. Biol. 6:801-810.

15. Erba, H. P., P. Gunning, and L. Kedes. 1986. Nucleotide sequence of the human gamma-cytoskeletal actin mRNA: anomalous evolution of vertebrate non-muscle actin genes. Nucleic Acids Res. 14:5275-5294.
16. Felber, B. K., M. Hadfzopoulou-Cladaras, C. Cladaras, T. Copeland, and G. N. Pavlakis. 1989. Rev protein of human immunodeficiency virus type-I affects the stability and transport of the viral mRNA. Proc. Natl. Acad. Sci. USA 86:1495-1499.

17. Gunning, P., P. Ponte, H. Okayama, J. Engel, H. Blau, and L. Kedes. 1983. Isolation and characterization of full length cDNA clones for alpha-, beta- and gamma-actin mRNAs: skeletal but not cytoplasmic actins have an amino-terminal cysteine that is subsequently removed. Mol. Cell. Biol. 3:787-795.

18. Hadjiolov, A. A. 1985. The nucleolus and ribosome biogenesis. Springer-Verlag, New York.

19. Hadjiolov, A. A., and N. Nikolaev. 1976. Maturation of ribosomal ribonucleic acids and the biogenesis of ribosomes. Prog. Biophys. Mol. Biol. 31:95-144.

20. Harders, J., N. Lukacs, M. Robert-Nicoud, T. M. Jovin, and D. Riesner. 1989. Imaging of viroids in nuclei from tomato leaf tissue by in situ hybridization and confocal laser scanning microscopy. EMBO J. 8:3941-3949.

21. Hayashi, S., I. C. Gillam, A. D. Delaney, and G. M. Tener. 1978. Acetylation of chromosome squashes of Drosophila Melanogaster decreases the background in autoradiographs from hybridization with [ $\left.{ }^{125} \mathrm{I}\right]$-labeled RNA. J. Histochem. Cytochem. 26:677-679.

22. Henderson, A. S., E. M. Eicher, M. T. Yu, and K. C. Atwood. 1974. The chromosomal location of ribosomal DNA in the mouse. Chromosoma (Berlin) 49:155-160.

23. Henderson, A. S., D. Warburton, and K. C. Atwood. 1972. Localization of ribosomal DNA in the human chromosome complement. Proc. Natl. Acad. Sci. USA 11:3394-3398.

24. Hidaka, M., J. Inoue, M. Yoshida, and M. Seiki. 1988. Posttranscriptional regulator (rex) of HTLV-I initiates expression of viral structural proteins but suppresses expression of regulatory proteins. EMBO J. 7:519-523.

25. Howell, W. M., and D. A. Black. 1980. Controlled silver-staining of nucleolus organizer regions with a protective colloidal developer: a one step method. Experientia 36:1014-1015.

26. Howell, W. M., T. E. Denton, and J. R. Diamond. 1975. Differential staining of the satellite regions of human acrocentric chromosomes. Experientia 31:260-262.

27. Huber, P. W., and I. G. Wool. 1986. Use of the cytotoxic nuclease alphasarcin to identify the binding site on eukaryotic 5S ribosomal ribonucleic acid for the ribosomal protein L5. J. Biol. Chem. 261:3002-3005.

28. Humason, G. L. 1967. Animal tissue techniques. W. H. Freeman and Co., San Francisco.

29. Huppi, K., R. Duncan, and M. Potter. 1988. Myc-1 is centromeric to the linkage group Ly-6-Sis-Gdc-1 on mouse chromosome 15. Immunogenetics 27:215-219.

30. Inoue, J., M. Yoshida, and M. Seiki. 1987. Transcriptional $(\mathrm{p} 40 \mathrm{x})$ and posttranscriptional ( $\mathrm{p} 27 \mathrm{x}$-III) regulators are required for the expression and replication of human T-cell leukemia virus type-I genes. Proc. Natl. Acad. Sci. USA 84:3653-3657.

31. Jones, T. R., and M. D. Cole. 1987. Rapid cytoplasmic turnover of c-myc mRNA: requirement of the $3^{\prime}$ untranslated sequences. Mol. Cell. Biol. 7:4513-4521.

32. Kalland, K. H., E. Langhofi, H. J. Bos, H. Gottlinger, and W. A. Haseltine. 1991. REX-dependent nucleolar accumulation of HTLV-1 mRNAs. New Biol. 3:389-397.

33. Kanamori, H., N. Suzuki, H. Siomi, T. Nosaka, A. Sato, H. Sabe, M. Hatanaka, and T. Honjo. 1990. HTLV-I p27 REX stabilizes human interleukin-2 receptor $\alpha$ chain mRNA. EMBO J. 9:41614166.

34. Keese, P., and R. H. Symons. 1985. Domains in virods: evidence of intermolecular RNA rearrangements and their contribution to viroid evolution. Proc. Natl. Acad. Sci. USA 82:4582-4586.

35. Kelly, K., B. H. Cochran, C. D. Stiles, and P. Leder. 1983. Cell-specific regulation of the c-myc gene by lymphocyte mitogens and platelet derived growth factor. Cell 35:603-610.

36. Lawrence, J. B., and R. H. Singer. 1986. Intracellular localization of messenger RNAs for cytoskeletal proteins. Cell 45:405415.

37. Lawrence, J. B., R. H. Singer, and L. M. Marselle. 1989. Highly localized tracks of specific transcripts within interphase nuclei 
visualized by in situ hybridization. Cell 57:493-502.

38. Long, E. O., and I. B. Dawid. 1980. Repeated genes in eukaryotes. Annu. Rev. Biochem. 49:727-764.

39. Luscher, B., and R. N. Eisenman. 1988. c-myc and c-myb protein degradation: effect of metabolic inhibitors and heat shock. Mol. Cell. Biol. 8:2504-2512.

40. Malim, M. H., J. Hauber, S.-Y. Le, J. V. Maizel, and B. R. Cullen. 1989. The HIV-I rev transactivator acts through a structured target sequence to activate nuclear export of unspliced viral mRNA. Nature (London) 338:254-257.

41. Maniatis, T., E. F. Fritsch, and J. Sambrook. 1982. Molecular cloning: a laboratory manual. Cold Spring Harbor Laboratory, Cold Spring Harbor, N.Y.

42. Miner, J., and B. Wold. 1990 . Herculin, a fourth member of the myoD family of myogenic regulatory genes. Proc. Natl. Acad. Sci. USA 87:1089-1093.

43. Murre, C., P. Schonleber McCaw, and D. Baltimore. 1989. A new DNA binding and dimerization motif in immunoglobulin enhancer binding, daughterless, myoD, and myc proteins. Cell 56:777-783.

44. Nepveu, A., and K. B. Marcu. 1986. Intragenic pausing and anti-sense transcription within the murine c-myc locus. EMBO J. 5:2859-2865.

45. Nigg, E. A. 1988. Nuclear function and organization: the potential of immunochemical approaches. Int. Rev. Cytol. 110:27-92.

46. Ploton, D., H. Bobichon, and J. Adnet. 1982. Ultrastructural localization of the nucleolar organizing region in nucleoli of human breast cancer tissue using a one-step Ag-NOR staining method. Biol. Cell. 43:229-232.

47. Potashkin, J. A., R. J. Derby, and D. L. Spector. 1990. Differential distribution of factors involved in pre-mRNA processing in the yeast cell nucleus. Mol. Cell. Biol. 10:3524-3534.

48. Prestayko, A. W., M. Tonato, and H. Busch. 1970. Low molecular weight RNA associated with 28 S nucleolar RNA. J. Mol. Biol. 47:505-515.

49. Ramsay, G., L. Stanton, M. Schwab, and J. M. Bishop. 1986. Human proto-oncogene $\mathrm{N}-m y c$ encodes nuclear proteins that bind DNA. Mol. Cell. Biol. 6:4450-4457.

50. Rhodes, S. J., and S. F. Konieczny. 1989. Identification of MRF4: a new member of the muscle regulatory factor gene family. Genes Dev. 3:2050-2061.

51. Rimsky, L., J. Hauber, M. Dukovich, M. H. Malim, A. Langlois, B. R. Cullen, and W. C. Greene. 1988. Functional replacement of the HIV-I rev protein by the HTLV-I rex protein. Nature (London) 335:738-740.

52. Schumacher, J., H. L. Sanger, and D. Riesner. 1983. Subcellular localization of viroids in highly purified nuclei from tomato leaf tissue. EMBO J. 2:1549-1555.

53. Schwab, M., H. E. Varmus, J. M. Bishop, K.-H. Grzeschik, S. L. Naylor, A. Y. Sakaguchi, G. Brodeur, and J. Trent. 1984
Chromosome localization in normal human cells and neuroblastomas of a gene related to c-myc. Nature (London) 308:288-291.

54. Siomi, H., H. Shida, S. H. Nam, T. Nosaka, M. Maki, and M. Hatanaka. 1988. Sequence requirements for nucleolar localization of human T-cell leukemia virus type-I pX protein, which regulates viral RNA processing. Cell 55:197-209.

55. Sodroski, J., W. C. Goh, C. Rosen, A. Dayton, E. Terwilliger, and W. Haseltine. 1986. A second post-transcriptional transactivator gene required for HTLV-III replication. Nature (London) 321:412-417.

56. Sommerville, J. 1986. Nucleolar structure and ribosome biogenesis. Trends Biochem. Sci. 11:438-442.

57. Spector, D. L., R. L. Ochs, and H. Busch. 1984. Silver staining, immunofluorescence, and immunoelectron microscopic localization of nucleolar phosphoproteins B23 and C23. Chromosoma (Berlin) 90:139-148.

58. Steitz, J. A., C. Berg, J. P. Hendrick, H. LaBranche-Cabot, A. Metspalu, J. Rinke, and T. Yario. 1988. A 5S rRNA/L5 complex is a precursor to ribosome assembly in mammalian cells. J. Cell Biol. 106:545-556.

59. Stroke, I. L., and A. M. Weiner. 1985. Genes and pseudogenes for rat U3A and U3B small nuclear RNA. J. Mol. Biol. 184:183-193

60. Tague, O. W., and S. A. Gerbi. 1984. Processing of the large rRNA precursor: two proposed categories of RNA-RNA interactions in eukaryotes. J. Mol. Evol. 20:362-367.

61. Tapscott, S. J., R. L. Davis, M. J. Thayer, P.-F. Cheng, H. Weintraub, and A. B. Lassar. 1988. MyoD1: a nuclear phosphoprotein requiring a myc homology region to convert fibroblasts to myoblasts. Science 242:405-411.

62. Thayer, M. J., S. J. Tapscott, R. L. Davis, W. E. Wright, A. B. Lassar, and H. Weintraub. 1989. Positive autoregulation of the myogenic determination gene MyoD1. Cell 58:241-248.

63. Thomas, K., J. del Mazo, P. Eversole, A. R. Bellve', L.-S. Lai, and M. Simon. 1990. Developmental regulation of expression of the LDH multigene family during mouse spermatogenesis. Development 109:483-493.

64. Urlaub, G., P. J. Mitchell, C. J. Ciudad, and L. A. Chasin. 1989. Nonsense mutations in the dihydrofolate reductase gene affect RNA processing. Mol. Cell. Biol. 9:2868-2880.

65. Weinberg, R., and S. Penman. 1968. Small molecular weight monodisperse nuclear RNA. J. Mol. Biol. 38:289-304.

66. White, K. N., T. Nosaka, H. Kanamori, M. Hatanaka, and T. Honjo. 1991. The nucleolar localization signal of the HTLV-I protein $\mathrm{p} 27^{\mathrm{REX}}$ is important for stabilization of IL-2 receptor a subunit mRNA by $27^{\text {REX }}$. Biochem. Biophys. Res. Commun. 75:98-103.

67. Zasloff, M. 1983. tRNA transport from the nucleus in a eukaryotic cell: carrier mediated translocation process. Proc. Natl. Acad. Sci. USA 80:6436-6440. 